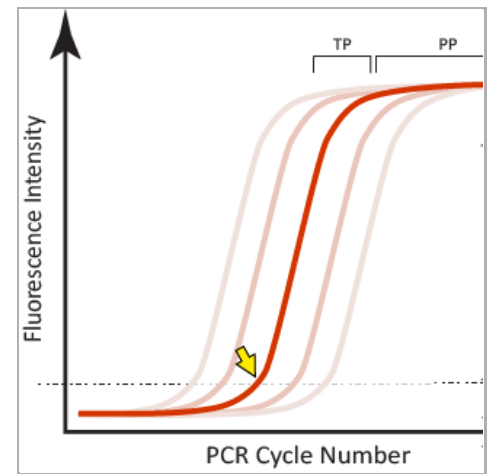

NOV 26, 2019

\section{open Әaccess}

\section{DOI:}

dx.doi.org/10.17504/protocol s.io.z3tf8nn

Protocol Citation: Judy A Northill 2019. Aichivirus realtime RT-PCR 2007 method. protocols.io

https://dx.doi.org/10.17504/p rotocols.io.z3tf8nn

License: This is an open access protocol distributed under the terms of the Creative Commons Attribution License, which permits unrestricted use, distribution, and reproduction in any medium, provided the original author and source are credited

Protocol status: Working We use this protocol and it's working

Created: Apr 16, 2019

Last Modified: Nov 26, 2019

PROTOCOL integer ID: 22355

Keywords: Aichivirus, AiV, Real-time, TaqMan, Aichi, RTPCR

\section{(3) Aichivirus real-time RT-PCR 2007 method}

Judy A Northill ${ }^{1}$

${ }^{1}$ Public Health Virology, Forensic and Scientific Services

ซิ Judy A Northill

Public Health Virology, Forensic and Scientific Services

\section{ABSTRACT}

A real-time assay to detect Aichivirus $A$ (AiV-A) in human samples. It is based in the 3'UTR region and has been employed in our laboratory since 2007.

\section{GUIDELINES}

- If using a different brand or model of real-time thermocycler, check the concentration of ROX is adequate.

- Method assumes the user is familiar with the thermocycler and software used to run the protocol.

\section{MATERIALS}

\section{STEP MATERIALS}

8 SuperScript $^{\text {TM }}$ III Platinum ${ }^{\text {TM }}$ One-Step qRT-PCR Kit Life Technologies Catalog \#11732088 


\begin{tabular}{|l|l|}
\hline Name & $5^{\prime}-3^{\prime}$ \\
\hline AiV-F-8046 & TGCTTCGGCACGCTTAGTT \\
\hline AiV-R-8151 & TGCARTACAACCAYGGCTTAGG \\
\hline AiV-8082-FAM & $\begin{array}{l}\text { 6FAM-CACTCCTCCATGGTGATATAAAGACCAC- } \\
\text { TAMRA }\end{array}$ \\
\hline
\end{tabular}

Aichivirus oligonucleotides

2 Reagents

\section{SuperScript $^{\text {TM }}$ III Platinum ${ }^{\text {TM }}$ One-Step qRT-PCR Kit Life Technologies Catalog \#11732088}

3 Reaction Set-up

- Assay has been used on both a Rotor-Gene 6000 / Rotor-Gene Q 5-plex using 100-place rotor discs and a ABI 7500 Fast real-time machine.

- Total reaction volume is $20 \mu \mathrm{L}$.

- Prepare sufficient for number of reaction plus a 'dead volume' usually 2 extra. Adjust as necessary if using a robotic dispenser.

\begin{tabular}{|l|l|l|}
\hline Reagent & Vol $\mu \mathrm{l}(\mathrm{x} 1)$ & $\begin{array}{l}\text { Final Reaction } \\
\text { concentration }\end{array}$ \\
\hline Nuclease-free water & 4.41 & \\
\hline Primer AiV-F-8046 $(100 \mathrm{pmol} / \mathrm{ul})$ & 0.06 & $300 \mathrm{nM}$ \\
\hline Primer AiV-R-8151 (100pmol/ul) & 0.06 & $300 \mathrm{nM}$ \\
\hline Probe AiV-8082-FAM $(100 \mathrm{pmol} / \mathrm{ul})$ & 0.03 & $150 \mathrm{nM}$ \\
\hline 2 X Reaction mix* & 10.0 & $1 \mathrm{X}$ \\
\hline ROX reference dye $(25 \mu \mathrm{M}) \star$ & 0.04 & $50 \mathrm{nM}$ \\
\hline $\begin{array}{l}\text { Superscript III/Platinum Taq enzyme } \\
\text { mix }^{\star}\end{array}$ & 0.4 & \\
\hline TOTAL & 15 & \\
\hline
\end{tabular}

*Superscript ${ }^{\circledR}$ III Platinum ${ }^{\circledR}$ One-Step qRT-PCR kit

Dispense $15 \mu \mathrm{L}$ to each reaction well.

Add $5 \mu \mathrm{L}$ of template, extracted RNA, controls or NTC (nuclease-free water). 
Total reaction volume is $20 \mu \mathrm{L}$

4 Amplification

\begin{tabular}{|l|l|}
\hline 1 cycle & 40 cycles \\
\hline $50^{\circ} \mathrm{C} 5$ minutes & $95^{\circ} \mathrm{C} 3$ seconds \\
\hline $95^{\circ} \mathrm{C} 2$ minutes & $60^{\circ} \mathrm{C} 30$ seconds* \\
\hline
\end{tabular}

*fluorescence aquistion step

$5 \quad$ Result analysis

The definition used for a satisfactory positive result from a real-time fluorogenic PCR should include each of the following:

1. A sigmoidal curve - the trace travels horizontally, curves upward, continues in an exponential rise and followed by a curve towards a horizontal plateau phase

2. A suitable level of fluorescence intensity as measured in comparison to a positive control (yaxis)

3. A defined threshold $\left(\mathrm{C}_{\mathrm{T}}\right)$ value which the fluorescent curve has clearly exceeded (Fig.1 arrow) and which sits early in the log-linear phase and is $<40$ cycles

4. A flat or non-sigmoidal curve or a curve that crosses the threshold with a $\mathrm{C}_{T}$ value $>40$ cycles is considered a negative result

5. NTCs should not produce a curve

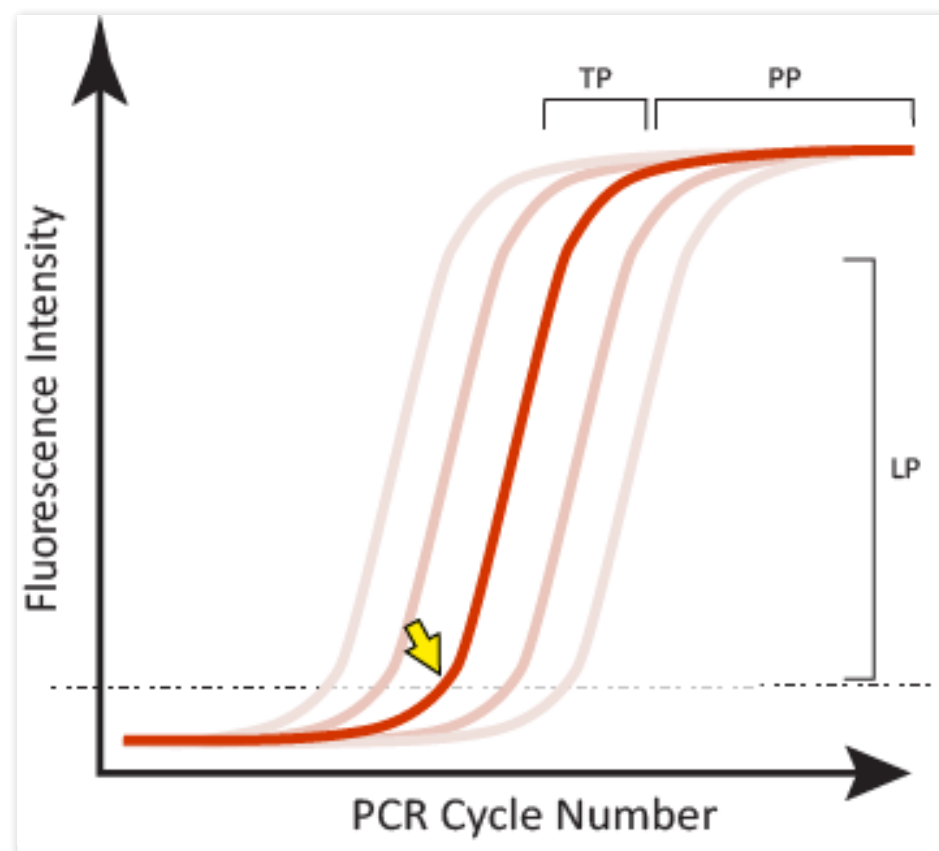


Figure 1. Examples of satisfactory sigmoidal amplification curve shape when considering an assay's fluorescent signal output. The crossing point or threshold cycle $\left(\mathrm{C}_{\mathrm{T}}\right)$ is indicated (yellow arrow); it is the value at which fluorescence levels surpass a predefined (usually set during validation, or arbitrary) threshold level as shown in this normalized linear scale depiction. LP-loglinear phase of signal generated during the exponential part of the PCR amplification; TP-a slowing of the amplification and accompanying fluorescence signal marks the transition phase; PP-the plateau phase is reached when there is little or no increase in fluorescent signal despite continued cycling. 